\title{
Teacher oral-language use as a component of students' learning environment in mathematics and science
}

\author{
Iris P. Hewitt-Bradshaw
}

\begin{abstract}
This paper adopts a qualitative approach to investigate classroom interaction in mathematics and science at the elementary school level. Specifically, it examines teacher oral language to elucidate the role it plays in shaping students' learning environment in a Creole language context. Using a framework of Halliday's systemicfunctional linguistics and Bourdieu's social theory, I analyze six instructional episodes in mathematics and science to uncover features of teachers' oral language that influence students' learning environment. The analysis suggests that teachers' classroom speech reflects the linguistic complexities of school mathematics and science, and can be challenging for learners' comprehension, especially in a second language situation. Sociolinguistic aspects of classroom interaction are also important to fully understand how teacher language affects student engagement in classroom discourse when their active participation is crucial to the understanding and use of academic language. Based on the findings and the research literature, I offer recommendations and a strategy for teachers who wish to use language in ways that better facilitate student learning across the curriculum.
\end{abstract}

\section{Introduction}

Although the major concern in language education has largely been on mothertongue language situations and foreign or second language education, there is now also a recognized body of literature that focuses on the role of language across the curriculum. One strand of such research has allowed inquiry into the complex process of how children are initiated into disciplinary fields such as mathematics and science using a language other than the primary one in which they think and communicate (Cummins, 1978, 1979; Lemke, 1990; Vollmer, 2007, 2009). This paper reports on an investigation of teacher classroom practice, specifically teacher oral-language use, with the aim of making recommendations for improving practice in the context of educational concerns about the challenges that students face when they learn disciplines in a second language or dialect.

\section{Learning through Academic Language}

Even when learners' first language is used as the official language of instruction in schools, they still need to develop proficiency in the academic language they are required to use in order to succeed in schools (Fang \& Schleppegrell, 2010; Lager, 
2006; Nagy \& Townsend, 2012; Schleppegrell, 2007; Zwiers, 2007). Research further suggests that students from low-income homes are at a disadvantage if they do not possess the linguistic capital that schools value (Vaish and Kiang Tan, 2008), and that teacher language can affect students' performance and success (Nassaji \& Wells, 2000; Tsay, Judd, Hauk \& Davis, 2011), as well as their social prospects and citizenship (van Goor \& Heyting, 2008). Furthermore, research has shown that classroom discourse patterns can both develop and impede students' language growth (Zwiers, 2007). Ernst-Slavit \& Mason (2011) support the view that a teacher's oral language in content areas sometimes provides learners with limited exposure to the specialized language of the disciplines, and that some terms and expressions that teachers use inhibit students' understanding. In light of this, teacher oral-language use can be considered a significant component of the students' learning environment. Here I use learning environment to refer to the physical, social, psychological, and linguistic conditions under which students learn in schools.

Concerns about the impact of teacher oral-language use are particularly significant in multilingual and multidialectal educational situations where the language of instruction is different from the students' vernacular. In fact, teacher language use emerged as a significant theme in a study I conducted in Trinidad and Tobago, a Caribbean postcolonial state where the official language of instruction in schools is Standard English (SE), while the vernacular of the majority of students is a related Creole language. Trinidad and Tobago is a political union of two small islands in the Caribbean region where the majority of the population speaks an English Creole, but the official language of instruction across the curriculum is SE. A similar situation exists in other Caribbean countries such as Jamaica and Barbados.

The complexities of this situation have been documented and debated in Caribbean research in education for a long time, and educators have highlighted linguistic, social, and psychological consequences for education systems (SimmonsMcDonald, 2004). The consensus is that the situation not only creates difficulties for students' language learning, but also for their learning across the curriculum, given the importance of language in schooling. Although there have been attempts to use research-based educational programs in Caribbean Creole language complexes (see for example Craig, 2006), the influence of linguistic and sociolinguistic research on educational policy, planning, and implementation in the Caribbean region is limited. In a context of official policy that promotes constructivist approaches to instruction, requires teachers to be models of SE use, urges respect for students' Creole language in the classroom, and recommends that students be allowed the use of their first language at the earliest levels of their schooling (Draft Syllabus for Primary School Mathematics, 1998; Syllabus for Primary School Science, 2003), teachers have to decide how much control to exert over the teaching-learning situation. For example, when they communicate orally, teachers must decide what to say and how it should be said. They must also be mindful of the length of time they speak, to allow students opportunities to express themselves. Competing expectations and responsibilities can create a dilemma of voice and agency for teachers. Reflection on and analysis of classroom language use is an important initial step in clarifying the 
process, resolving confusion, and making informed decisions for practice. Interestingly, the added challenge of using SE academic language in Creole language complexes of Caribbean states has not been the subject of much discussion. Debate has traditionally focused on the most effective methods and approaches to language teaching and learning, the role of vernacular varieties in education, and the impact of negative attitudes towards such varieties.

The issue that is the subject of this study is part of a wider debate about multicultural education, and the ways in which schools can acknowledge and respond to the language of different communities from which children come. Language is an important part of learners' cultural identity, and where the form and use of their language differ from the one sanctioned by the school, the consequences for children's learning must be considered. The work of Heath (1983), Delpit (1995), Cazden (2001), and Valdés (2004) underscore the importance of accommodating cultural diversity in classrooms, since language is crucial to the way children's success and achievement are measured in schools. Furthermore, concerns are frequently articulated about low levels of student achievement in mathematics and science. This study can therefore contribute to inquiry into classroom processes since it provides description and analysis of classroom teaching and learning at the primary level in the content areas of mathematics and science. It can also contribute to the curriculum of teacher education programs, and has the potential to encourage practicing teachers to be reflective about their language use when they facilitate student learning across the curriculum.

\section{Theoretical Framework}

Systemic-functional linguistic theory (Halliday, 1978, 1993) provides a sociolinguistic framework that allows an analysis of teacher language. From Halliday's perspective, language variation is viewed in terms of the diversity in structures and processes in society, with language use in speech communities being seen as functional, communicative events that create meaning in a specific social and cultural context. It is also part of a semiotic process of making meaning through the use of specific linguistic choices. Basic concepts of systemic-functional linguistics are text, context, tenor, and mode (Halliday, 1978, 1993). Text is produced in the course of an event that occurs in a social context. This context is framed by the social activity taking place, the tenor or relationship among the participants, and the mode or rhetorical channel through which communication takes place. Halliday used the term "register" to refer to a "set of meanings that is appropriate to a particular function of language, together with the words and structures which express these meanings" (1978, p. 175). The variety of language is appropriate to a particular type of social situation, serves a specific function, and is characterized by domain-specific vocabulary, appropriate styles of meaning and words of argument. Registers link texts (oral, written, or visual) to their context. By virtue of context, purpose and form, there will be differences between the register of a school discipline and the everyday language that students use at home. Viewed in terms of participants, form, and context, each discipline in the school curriculum can thus be considered a register that constructs knowledge in specific ways. Schools attempt to teach 
students to use this register to participate effectively in subject-specific ways of knowing. The structure and the conceptual demands of content-area texts affect the sense that learners make of those texts, how learners respond to them, and how they learn from them (Vacca, Vacca, \& Mraz, 2011). Teachers' oral language is an example of one of the texts that students must negotiate in order to learn mathematics and science. Students' prior language and experiences must of necessity be considered in any analysis of their understanding and their contribution to classroom discourse.

While systemic-functional linguistics provides a framework for understanding the existence of different language varieties in the classroom, it is limited in explaining the conflict and tensions that are at times overt, but can also operate covertly, in schools and classrooms. From a sociological perspective, Bourdieu (1977) offers a theory of practice with constructs such as "habitus," "field," and "linguistic capital" which help us to understand teacher language use in teaching-learning situations where students only partially share the language, behavior and attitudes promoted in schools. Bourdieu viewed schools as a formation of the state that reflects the knowledge and values of the dominant social groups. Through the process of socialization, children acquire cultural background, knowledge, and dispositions that equip them with social and linguistic capital. Only those forms of capital associated with dominant social groups are valued by schools, to the disadvantage of those groups with different knowledge, dispositions and lifestyles. In such a situation, social capital and linguistic capital are critical resources for success in schools. Habitus is an "expression of subjectivity" (Grenfell, 2009); a set of dispositions that people acquire through their social roles. It is thus a product of routinized, conscious and unconscious habits that are evident in people's behavior, including their language and language use. The structures constitutive of a particular type of environment

([e.g. the material] conditions of existence characteristic of a class condition) produce habitus, systems of durable, transposable dispositions, structured structures predisposed to function as structuring structures, that is, as principles of the generation and structuring of practices and representations which can be objectively "regulated" and "regular" without any way being the product of obedience to rules. ...

Habitus guides teachers' actions and decisions and shapes their language and language use since ... agents are possessed by their habitus more than they possess it; this is because it acts within them as the organizing principle of their actions, and because this modus operandi informing all thought and action (including thought of action) reveals itself only in the opus operatum. (Bourdieu, 1977, p. 72, 18)

Bourdieu suggests here that action is both conscious and subconscious. Because the culture of the dominant group is privileged in schools, social stratification is reproduced due to unequal access to the valued social and linguistic capital. Teachers and students operate within a "field"; that is a 
Network ... of objective relations between positions. These positions are objectively defined, in their existence and in the determinations they impose upon their occupants, agents or institutions, by their present and potential situation ... in the structure of the distribution of species of power (or capital)[.] (Bourdieu \& Wacquant, 1992, quoted in Grenfell, 2009, p. 441)

The usefulness of Bourdieu's theory for a language-in-education study like this one is the opportunity it presents to analyze the nature of academic discourse and understand how it contributes to classroom knowledge and organization, and how it can impact student learning. The concepts of field, habitus, and linguistic capital are useful to understand teacher language as a facet of teacher practice in the field of education where tensions exist between the linguistic capital and the behaviors and attitudes that have been internalized by teachers and students.

\section{Research questions}

The following questions were used to explore the central issue, in keeping with the theoretical framework outlined above:

1. What role does teacher oral language play in shaping students' learning environment in mathematics and science?

2. How can teachers increase their awareness of their language use to foster classroom environments that better enable student learning?

\section{Methodology}

This study emerged from a larger case study of the language challenges that students face when they are taught mathematics and science in SE in a situation where their vernacular is a Creole-related language. The case study adopted a qualitative, ethnographic approach to investigate three elementary classroomsInfants (5 - 7 years old), Standard 1 (7 - 9 years old) and Standard 4 (10 -12 years old) - at one purposely selected school site in a community located on the outskirts of a city in Trinidad. Four trained teachers participated in the study: one in Infants, two in Standard 1, and one in Standard 4. The students were all from working-class homes in the community. Data for the study included documents, interviews, classroom observation, lesson transcripts and fieldnotes as data collection methods. Data analysis was inductive and interpretive (Creswell, 2008) and involved techniques of coding, categorizing, and identifying salient themes across the subcases. All data were read repeatedly and coded. Following Miles and Huberman (1994), the data were then subjected to a process of data reduction. This involved a selection of segments of the data that would elucidate the research questions and a formation of categories and themes on the basis of constant comparison. Teacher language emerged as one significant factor in the three classrooms observed. This paper utilizes illustrative instructional episodes from lesson transcripts recorded for the main study. Stake (2010) offers a useful description of the process: 
Much qualitative research is based on the collection and interpretation of episodes. Episodes are held as personal knowledge more than as aggregated knowledge ... An episode has activities, sequence, place, people, and context. Some of the more useful-appearing episodes, the ones we think of as "patches," need to be studied, analyzed, their parts seen and seen again. We observe them, and we record other people's observations. We interpret them and seek other interpretations. We put things together and take them apart ... And sometimes we put the facts together into new wholes, into new interpretations, into a new patch. (133-134)

The following communicates my interpretation of the instructional episodes within the theoretical framework previously described.

\section{Findings}

The commentary is an analysis of six illustrative episodes in mathematics and science from three classrooms. They exemplify the salient issues interpreted within the theoretical framework discussed previously, in a context where students from a working-class background, speaking an English-related Creole vernacular, were being taught in a variety of Trinidad SE. All names used in the episodes are pseudonyms.

\section{Illustrative Episode 1 - Which is most liked or least liked?}

At the infant level, a mathematics lesson on statistics provided examples of challenges arising from the teacher's use of the register of a school discipline. Ms. Blake began the lesson with an activity involving comparison, and then directed students' attention to their books where a pictograph was already drawn representing children and the flavors of ice cream they liked.

T: Okay, this is strawberry. Let's count how many children here.

Ss: (counting with T.) 1, 2, 3, 4, 5 .

T: 5 children like strawberry.

S: I ready.

T: The next one is ... chocolate. One child likes chocolate. And how many children like

vanilla? (counting with some students) 1, 2, 3 .

S: (shouting) 3!

T: So which flavor is the most liked?

(Students do not respond to the question)

T: Which flavor do the children like most?

S: (shouts) None!

S: Vanilla.

T: Vanilla? How many children like vanilla?

S: 3

T: And how many like strawberry?

S: 1 
Ss: 5

T: Which flavor is the most liked?

Ss: (do not respond)

S: (after a short while) Strawberry.

T: Strawberry, because five children like strawberry.

At this point, the teacher repeatedly explained the term most liked. She expressed the central idea in different ways: most liked was explained as like most. The term was also repeated. However, when it was apparent that many students still did not understand, the teacher eventually instructed them to write the correct answer, strawberry. She later addressed their difficulty in determining whether they should put the number of persons or the word indicating the flavor. She positioned students as responders to a third party, "they," who supposedly asked the question that they wanted to know the answer to.

T: You want to know what flavor not how many. They're not asking you how many. Which flavor, and the name of the flavor, Michael?

Michael: Strawberry.

T: That's right, so put the name strawberry.

S: (Makes a comment that is not clear)

T: Um, the other flavor is chocolate and ... One child likes chocolate... (breaks off again to rebuke some students who are not doing their work and sends one to stand near the door. She continues circulating and instructing individual students.)

T: Okay, so put the word strawberry there, okay?

T: Now the question is, which flavor is the most liked? Which flavor is the most liked?

(Students speak, but do not respond to the question. One complains about another student).

T: Paul, sit down. Michael?

Michael: Strawberry.

T: Right. Are you going to write 5 here or strawberry?

Ss: Strawberry.

T: Not the number of children, but which flavor.

S: (loudly) Chocolate!

T: Put strawberry.

As the lesson continued, the same difficulty arose when the teacher used the term liked least, so that, at the end, most students experienced difficulty with the concepts of liked most and liked least. The teacher indicated which answer to write in the appropriate spaces in their books.

This episode shows how problematic teacher language use of terminology from the register of a school discipline can be for learners, irrespective of how simple terms and structures appear to be. The teacher's use of pronouns in the episode is also significant. She used "you" in reference to the students' presence or voice in the mathematics problem and introduced a third person "they" as the party 
asking the question. This raises the question of agency in teaching and learning disciplines. The teacher told the students what "they" wanted to know; stated that they were being asked the question by "they"; and she told them on several occasions to put strawberry as the answer. Teacher language can be examined to determine how it establishes agency in classroom discourse (Wagner, 2007). Close examination of the prevailing pattern of classroom discourse reveals that it is one of teacher initiation, student response, followed by teacher evaluation or feedback (IRF) as described in Cazden (2001). This ensured a predominance of teacher talk in classroom discourse and limited meaningful oral participation by students who gave one or two word responses in this teaching-learning segment.

\section{Illustrative Episode 2 - Saying the correct thing}

Although teacher talk dominated classroom discourse at the infant level, compared to the older students, infants enjoyed a greater degree of liberty with respect to how and when they spoke, frequently responding in a chorus or loudly shouting out answers. The teacher rebuked students mainly on occasions when they were inattentive or off-task, or when the noise level became excessive. However, she sometimes praised their use of SE as a model.

Luke: Miss, I am ready!

T: So am I. See how Luke always says the correct thing? He never says 'I ready' or 'I is ready'. He always says 'I am ready'.

Luke: I am ready.

T: I'm coming, I am coming. Luke, 5 children like strawberry, so draw 5 little children next to the word strawberry.

S: I like strawberry.

T: O'Neal, next to the word strawberry, draw 5 little children.

S: Where the word strawberry?

S: Miss...

(Children chat while following instructions and T circulates and directs them how to complete the work in their books).

The teacher's praise for the use of the structure "I am ready" encouraged Luke to repeat it. Later in the lesson, two other students echoed the sentence and others fashioned sentences using SE syntax, thereby receiving the teacher's praise. Although I never heard this teacher rebuke students for using Creole in the classroom, the attitude that one variety is superior to the other is implied. Students discerned what the preferred way of speaking was and some responded accordingly, getting an opportunity to practice SE grammatical structure. This episode illustrated the way in which one variety was privileged over others in the classroom.

\section{Illustrative episode 3 - Don't break the rules}

To varying degrees, teachers used language to regulate students' participation in classroom discourse and set boundaries that limited the time, manner and purpose 
of their verbal responses. This was frequently demonstrated when teachers sought to regulate students' talk to have it conform to their expectations of what were acceptable ways of conducting classroom discourse. In science at the Standard 1 level, students played with the words and chatted generally at the beginning of the lesson. However, the mixing of the formal and social did not meet with the teacher's approval and she immediately invoked classroom procedures to regulate their behavior.

T: Hello, sit up. Turn to page 13.

S: Tirteen.

S: Tuteen?

T: Thirteen.

S: Miss, I fine it.

S: I done fine it aready.

S: Ah fine it.

(Students are speaking generally as they find page 13)

S: $1-3$.

T: Yes, 1-3. Turn to page 13.

(Page 13 shows a picture of the skeletons of three animals. There is much talking as students try to locate page13)

T: Hands up, out, up, out, down. Now this morning, I want you to look up here. .... Right. Keep your eyes here. Now, there's a picture on page 13. Do you see that picture?

Ss: Yes, Miss.

T: Right, now remember, I don't like people shouting at me, right?

The teacher invoked the "hands up, hands out" routine to address student vocal play and what she anticipated would be their "shouting" at her. These were contentious issues in this lesson and in most lessons I observed in this classroom. Even when they were focused on a teacher-directed task, students' freedom to talk was controlled within teacher-determined boundaries. In addition to the manner in which they responded, their answering without being called was also deemed unacceptable. What Ms. Bajnath considered to be acceptable speaking behavior was so important to her that she had negotiated what she referred to as a "deal" with them prior to the start of the lesson.

T: Alright, you said that already. Very good. That is so. When you go to the doctor, and he takes an x-ray, you are able to see the bones in your body.

$S:$ And he does give you a picture.

(Students give rapid responses to elaborate on the response.)

T: (Loudly) Listen, listen, wait up. (In a softer tone) Remember this entire week we had a deal?

Ss: Yes, Miss.

T: And what was the deal? You don't shout at me, I don't (pause) beat you. Right. Don't shout at me. Good. (Standing in front of the class and 
demonstrating.) Now, I would like you to take your hand, and pass it along the back of your friend.

(Students turn to seatmate and trace as teacher shows).

The teacher thought students' talk created noise because they "shouted," so she responded very emotionally, and her tone varied from loud and angry, to soft and reasoning. This scenario was repeated at several junctures of the lesson to address what she saw as breaches of the speaking rules. At times, silent reprimands momentarily suppressed students' enthusiasm and participation; then their exuberance would resurface, and loud, animated talk ensued, until the teacher eventually stopped the lesson. Her rebuke was a code-mixing of Creole and Standard English.

(Students are calling out to the teacher, answering and commenting all at once)

T: Stop, stop. (Pause) Ah have ah feeling you all behaving like this because Miss (the researcher) is here. ... and, erm it getting a little bit annoying now. Because, I doh think we have disorder in this class and I am getting a little bit, erm, a little bit annoyed at the fact that you all know the rules, and you all are still (pause) ...

S: Breaking it

T: (continuing) breaking it. Very good. Okay. Now remember, if you have something to say...

S: Put up your hand.

S: Put up your hand.

T: (sarcastically) Oh, both of you know? Raise your hand, wait till I point to you, and then answer me. You don't go shouting at me. I know that you are excited at the pictures, and I am excited too, but remember, I only have two ears. So speak quietly, okay. Right. Let's go back to the picture of the human skeleton there. What's a human skeleton?

S: The bones in our body.

T: The bones in our body.

Ss: Miss, miss. (loudly)

T: (pauses and looks sternly at them). Yes, now, let's tack back a bit, go back a bit. My friend here told me that the skeleton helps us keep our shape. Okay, why do we need to keep our shape?

S: (beginning to respond loudly) Miss...

T: Don't shout at me again.

The teacher conveyed her annoyance about what was happening and clearly indicated that students' talk created "disorder" by "breaking the rules." She 
emphasized expected procedures: "Put up your hand. Wait till I point to you, and then answer me." The manner in which they were expected to talk was also specified: "Speak quietly." When the lesson continued and they began to answer loudly, the teacher once again reined in their animated responses. It was perhaps ironic that, in this class, students usually exhibited high levels of interest and participation. Their enthusiasm frequently resulted in much discussion and talk which breached the limits set by the teacher, who seemed to act on the basis of her habitus. From one perspective, students' desire to elaborate on their responses possibly created a dilemma for the teacher, whose concern was to cover a specific amount of content in a limited period of time.

In a post-lesson discussion on the lesson, Ms. Bajnath indicated that she did not think differences between the language of instruction and students' first language created significant difficulties for her learners. She thought her greatest challenge came more from "controlling their behavior" than from making herself understood. She spoke about their "energy" and thought them "hyperactive." When she was suddenly transferred from the school and another teacher assumed duties with the class, the level of conflict between teacher and students over this aspect of their classroom behavior was not as high, though there were areas of similarity. This led me to conclude that Ms. Bajnath's responses and attitude must be understood in light of her personal history and experiences, as well as within the context of her practice in the wider society where the language and culture of different groups were valued differently. Her attitude and dispositions were similarly apparent in the next episode with the same class in mathematics.

\section{Illustrative episode 4 - Color your shape}

In a lesson on fractions, the following excerpt was recorded in my field notes:

[Teacher] instructed them to take the distributed shapes and fold in exactly over the other part. She encouraged them to check their peers to determine whether they followed instructions. Students formed groups and compared their shapes. They then were instructed to take the circle and do the same thing. She questioned them about the folded circle. She asked them to state what they observed. Students shouted various responses: "Miss a half a circle; a semi-circle; mine like a house; mine like a butterfly; a semicircle; a half a circle; an ice-cream cone; a raindrop." (They call out different responses in quick succession).

The teacher then held up the shape of the heart, and another shape. The classroom climate shifted from relaxed to tense as the noise level increased with students consulting with each other and comparing shapes. The teacher instructed students to color one side of the shape. She walked around and urged students to color quickly. (It seemed that she was attempting to have them expend energy and focus on a single task. Her tone became more authoritative). 
The students continued to color furiously at the teacher's urging and periodically held their colored shapes up for her inspection and approval. $\mathrm{T}$ said, "Put coloring pencils down. Sit up." She then colored a sample held against the board and asked class what they noticed. One said that it formed a "next shape"; another responded that the two were the same. The teacher asked how many were formed that were the same, but students did not respond. She repeated the question and a student replied "two."

In response to perceived "noise," the teacher urged students to color their shapes to keep them engaged. This succeeded in silencing the students, who became absorbed in vigorous activity. The teacher's response to an increasing level of student talk was to assume an authoritative stance from which she issued short, precise instructions for students to follow procedures to accomplish a task. The students were effectively silenced and were slow to respond to subsequent teacher questioning. They were, however, eager to obtain the teacher's approval of the models they had worked on during the lesson, and were pleased when she praised samples held up for her inspection. Inequity in status of teacher and students was quite evident in this episode and when increased student talk appeared to threaten teacher control, like the "hands up, hands out" routine previously employed, the coloring strategy regained some measure of control and silence.

Both Episode 3 and Episode 4 show how teacher language establishes the discursive patterns in the classroom. Depending on the dispositions of the teacher, the quantity and quality of student engagement with classroom discourse can be encouraged or restricted. Furthermore, teacher language shows direct and indirect links to other aspects of pedagogical practice; in this case, language is used as an instrument for classroom control.

\section{Illustrative Episode 5 - Questioning, explaining, and codeshifting}

At the highest class level, Standard 4, classroom discourse was most dominated by teacher talk. The style of teacher explanation and questioning often exhibited the same complexity as the other classroom texts that students had to negotiate in their lessons. Many questions were simple, e.g., display questions such as: "How many millitres in a litre?" In some sequences, Ms. Ramlogan posed multiple questions in one turn. When students seemed not to understand the line of questioning, they remained silent. At times, even when they offered a response, they did so in a soft, tentative tone of voice. Their silence or incorrect responses were often taken to mean that they either were not listening, or were not thinking.

In one lesson on the strand Measurement in mathematics, the language that the teacher used to explain how to work with different units of measurement in mathematics revealed an interesting use of terms, some of which students appeared to have internalized.

T: The same way when we are going to do addition and subtraction of litres and millilitres, we are going to look at that same idea, right. How many millilitres in a litre? 
Ss: (together) 1000.

T: Right, so when you come to add our millilitres column, right, we are going to see, anytime we get more than a thousand, what are we going to do?

Some Ss: Convert it.

T: Convert it to ... litres

Ss: Litres (said simultaneously with T).

$\mathrm{T}$ : Take it across to the litres column. In your litre column, every thousand millilitre is going to be how much litres?

Ss: One litre.

T: One litre, right. And in the same way, now I want you to think. I want your brain to start thinking. When we are doing subtraction now, right, and we are subtracting, and let's say we reach up to thousand, right, we reach up to thousand and we subtracting by the hundreds and we want a hundred, what do we do?

S: Take a hundred...

T: Wait, we subtracting thousand, hundreds, tens, and ones and we reach onto the hundreds column, but we don't have enough hundreds in the column, what do we do?

S: We go to the thousand column.

T: And we go to the (slight pause) thousand column. And when we go to the thousand column, how much are we borrowing? Are we borrowing one? What in fact are we borrowing?

S: A thousand

T: One (stressed) thousand. We are borrowing a thousand (stressed), and we are taking it across to the hundreds column, right. In the same way, when we are doing subtraction (stressed) of the litres and millilitres, we are going to be looking at that same procedure. So we have to be thinking. Are we going to be borrowing a 1 from a litre to bring it to the millilitres?

Ss: (Mixed responses as some students say "yes" and some say "no")

The use of informal vocabulary in this lesson indicated a use of language that was either specific to this teacher or the school context and which was used to explain how to work with units or values to perform this procedure in mathematics. In this case, common verbs that students would ordinarily use in other contexts were applied in relation to mathematical concepts to follow procedures. Table 1 lists some of those terms that were identified in the episode, and my interpretation of each one in the context in which it was used by the teacher.

In some cases, ellipsis was a textual feature of the teacher's speech when words were omitted from speech with the expectation that they were easily retrievable from the context, for example, "reach up to...". It can also be difficult for 
listeners to identify the referents of pronouns such as "it" and "that" in oral communication. Given the multiplicity of terms, the grammatical structures, textual features, and subject content used with different modes of representation such as written texts and graphic representations, the challenges of constructing meaning from oral text is a complex process. Teachers need to understand how such language components work together to enable or inhibit student understanding of oral discourse in content areas, and ultimately their learning. On this occasion, students were expected to understand that, in some contexts, "1" represented many; therefore conversions had to be made. Few students were confident at this stage to volunteer responses when the incorrect procedure seemed to be validated by their teacher in a move that tested students' certainty in their knowledge of mathematical procedures.

At this class level, students were more tentative and timid in their responses when compared to their younger peers in Infants and Standard 1. There were hardly any verbal clashes between teacher and students with respect to the level of noise generated by eagerness to respond or animated discussion. In fact, students seemed to have been schooled into silence and scarcely took risks for fear that their answers were incorrect. Their short responses contrasted with the extended teacher utterances throughout the lessons observed.

\begin{tabular}{|l|l|}
\hline \multicolumn{1}{|c|}{ Term used } & \multicolumn{1}{c|}{ Meaning in context } \\
\hline Take it across & Move the value across to the other column \\
\hline Doing subtraction/addition & $\begin{array}{l}\text { Subtracting/taking away one value from } \\
\text { another }\end{array}$ \\
\hline Reach up to/onto ... & Reach the limit of ... \\
\hline Want a hundred & Want one hundred units \\
\hline Go to the thousand column & Go to the column with units of a thousand \\
\hline How much we borrowing/borrowing a 1 & $\begin{array}{l}\text { How much we are taking from another unit } \\
\text { column/Taking one unit from another column }\end{array}$ \\
\hline Bring it to ... & $\begin{array}{l}\text { Add the value of the units taken from one unit } \\
\text { column to another column }\end{array}$ \\
\hline Taking it across to the hundreds column & $\begin{array}{l}\text { Add the value of the units taken from a column } \\
\text { to the column with units of a hundred }\end{array}$ \\
\hline Bring it to the millitres & $\begin{array}{l}\text { Add the value of the units taken from another } \\
\text { column to the units of a millilitre }\end{array}$ \\
\hline
\end{tabular}

Table 1. Terms used by teacher in a mathematics lesson - Standard 4

\section{Illustrative episode 6 -Who eats and who is eaten}

Presenting concepts in science sometimes meant that teachers used grammatical patterns that contrasted with those used in students' vernacular to express relationships. In this episode from a Standard 4 lesson on Food Webs, teacher language reflected morphosyntactic differences between Standard English and Trinidad English Creole when she explained a key concept. Students initially had difficulty understanding teacher explanation of a food web. Part of the difficulty 
stemmed from the use of the phrases "eats" and "is eaten by" to describe the relationship between different animals and things in the food web.

At the start of the lesson, Ms. Ramlogan asked students to describe what they were seeing on page 66 of their textbook, which showed a picture of a food web. She questioned them on several aspects of the diagram to elicit their understanding, focusing specifically on the direction of the arrow and inviting comparison of the shape of the arrow in a food web to its shape in a food chain. She asked students to describe what was happening in the diagram they were viewing. Through questioning, the teacher sought to elicit what the arrow represented, as well as the students' understanding of the relationship between the animals depicted in the diagram, and whether students knew the different parts of the arrow such as the head. The teacher continued to question students and when she received several incorrect responses, she drew the following diagram on the board:

eaten by

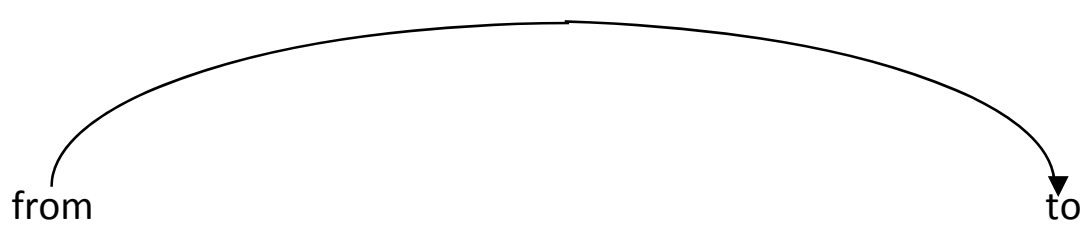

Figure 1. Graphic used in a science lesson on Food Webs - Standard 4

She then elicited from students what the arrow represented, and established the relationship between the two animals in terms of those who ate and those who were eaten:

S: The fish is eaten by the kingfisher.

T: How many things eat the fish?

(Some students said one and some said two).

The teacher added to the diagram already drawn on the board and continued the lesson.

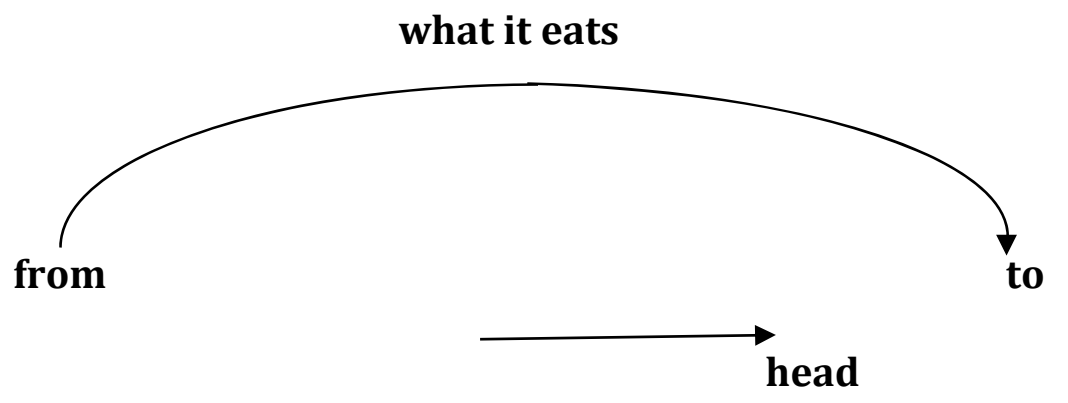


Figure 2. Developed graphic used with teacher explanation - Standard 4

T: What do you call this part (pointing to the head of the arrow)?

S: The pointy part

S: The head

(The teacher wrote "head" on the board and told students that it was called the head).

T: What else eats the fish?

(Students are silent)

\section{T: Anything else?}

S: The insect eat the fish.

One student responded and again confused "eats" and "is eaten by," and the teacher wrote under the diagram on the board:

"The insect eat the fish"

"The insect eaten by the fish"

She then made the difference between "eat" and "eaten by" a teaching point of the lesson. Here it was evident that the passive expression is eaten by challenged some students and the teacher responded with a minilesson because the term was so central to understanding the concept of a food web. She asked the class if there was a difference between "eats" and "is eaten by." Then she called a student to read the sentences and match them to the arrows that symbolized the two meanings. Some time was spent discussing, matching, and verbalizing so that students would grasp the concept. The structure "is eaten by" is a passive construction that is not commonly used in students' vernacular. Comparable Creole structures that students might use to convey similar meaning would be "does eat" for habitual action, and "does get eat by" for the passive construction. The fact that the SE structure must be matched by an arrow moving in a specific direction means that students must understand the grammatical structure in relation to a graphic representation to correctly convey the meaning in science. The situation thus required the teacher to consider the language of students to help them attain the concepts that were central to the lesson. In this case, Ms. Ramlogan recognized a difficulty, and spent some time giving her students the language practice they needed. However, this was not done with reference to their vernacular, which is useful in this context since research in Caribbean English Creole has highlighted the difficulties created by the overlap in the lexicons of Caribbean English Creole and Standard English (Craig, 2006; Simmons-MacDonald, 2004). This necessitates teacher knowledge of how the language systems differ.

Another important aspect of teacher language in this lesson was the degree of lexical and conceptual density in short segments of the lesson. Table 2 lists some of the terms students had to transact in order to understand the concept that was being taught. The teacher initially reviewed some of the terms and expressions, 
since students had encountered them in previous lessons, but others were new and students had to develop concepts for them in order to understand food webs. Teacher explanations accompanied visual or graphic representations to symbolize relationships between and among plants and animals in a food web, and wordsverb constructions and prepositions-were required to match the direction of the arrows used to indicate how the plants and animals were interconnected.

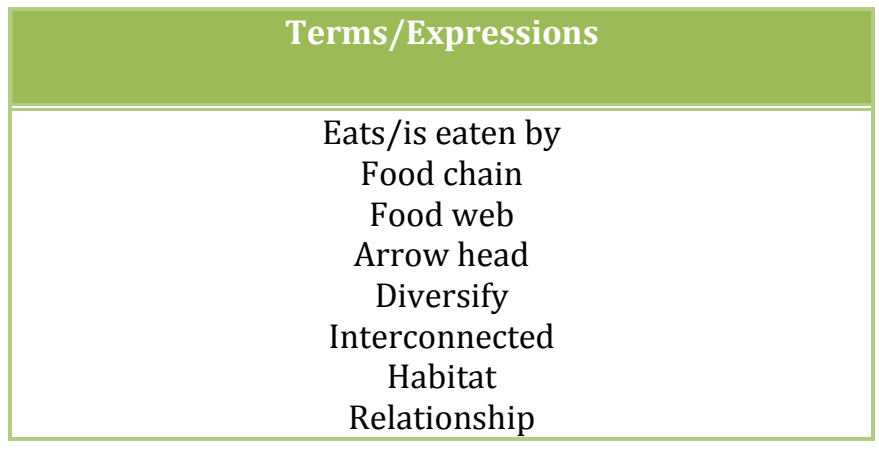

Table 2. List of terms and expressions in a Standard 4 science lesson

Students were supported throughout the lesson with other vocabulary items that were not specific to science. For example, when they had problems reading aloud the note she had written on the board, the teacher identified the terms they had difficulty pronouncing, underlined them and had students repeat the word. She challenged them to give the meaning and treated the word in the context of the note written on the board. In this way, teacher oral language supported student understanding of subject content.

\section{Discussion and Recommendations}

This study sought first, to uncover the role that teacher language plays in shaping students' learning environment, and second, to identify the ways in which teacher awareness of language use can fashion facilitative learning environments. Examination of teacher oral classroom language provided evidence of the use of terminology of the registers of mathematics and science with the potential to both build and challenge students' understanding. The degree to which students derive meaning would depend on whether

- the terms or structures are new to students;

- students previously heard the terms or structures, but are unaware of the precise meaning;

- terms or structures are similar in form but different in meaning to those used in students' vernacular; or

- terms or structures are similar in form and meaning to those used in students' vernacular.

If terms or structures in school disciplines are similar in both form and meaning to those in students' first language or dialect, then learners possess the 
linguistic capital to negotiate content easier than if this was not the case (Zevenbergen \& Gates, 1998). In addition, teacher oral language can be linguistically and conceptually complex. It would be difficult for listeners to arrive at the interpretation intended by the teacher if they are not equipped with the resources to do so. It therefore requires teacher awareness of pertinent comprehension processes. In this regard, teachers' oral language can either facilitate or inhibit student comprehension and so constitute a positive or negative factor in their learning environment.

In the current study, there were few recorded instances of teachers rebuking students for the use of their vernacular in the classroom. This contrasts with previous research in Caribbean sociolinguistic complexes, for example Carrington (1990), which drew attention to the consequences of negative attitudes to the use of Creole in the classroom. However, teachers sometimes praised students for their use of SE. On some occasions teachers switched codes and used Creole to rebuke students.

Teachers spoke from a position of authority and power socially vested in them to organize instruction, and this established the tenor or relationship of participants in classroom interaction. Teachers expected specific patterns of student behavior, and their speech, as other aspects of their pedagogic practice, reflected their dispositions, values, experience and training. Grenfell (2003, p. 11) cited an observation from Vandenberger (1974) that "authority is involved in every pedagogic relation." Grenfell added that authority is constituted within a field and is expressed and impacts on individual habitus, taken as internalized attitudes and routinized behaviors (Bourdieu, 1977). These in effect determine how teachers communicated when they attempted to fulfill their roles as teachers. In the context of the study, the habitus of teachers was fashioned by individual history and experiences in a society with a colonial past, and which valued specific cultural practices over others. The classroom is a subset of the field of education in which teachers conduct their practice and exhibit their professional habitus. As part of this practice, their oral language in the classroom supported or challenged student understanding and participation in classroom discourse. In addition, entrenched discursive patterns of classroom discourse, marked by dominant teacher talk, can give students little sense of agency or of the way things are done and expressed (Wagner, 2007). In one episode in the study, the teacher, perhaps unconsciously, through the use of pronouns positioned the learners as responders to an absent third party. In other episodes, students responded to teacher questioning with silence. One of the ways in which this can be interpreted is as evidence that they excluded themselves or were excluded from classroom discourse.

Based on the findings, it would be useful for educators to record instances of their oral language use in the classroom to discover what it reveals about their assumptions, dispositions, and pedagogic practice. The information can be further analyzed to ascertain features that promote or inhibit students' learning. Grenfell (2003) suggested that the process of self-examination can help to make teachers sensitive to mechanisms of exclusions and inclusions inherent in teacher 
pedagogical discourse, and which permit teachers' "unknowing collusion" in constructing environments that contribute to student failure. Focused and informed reflection on practice therefore has the potential to increase teacher level of consciousness about classroom language, and increase knowledge as a basis for action. Thus, educators need to closely examine classroom processes to understand how oral language functions, especially in a context where students' language and ways of speaking are not valued in schools. Although language attitude and behavior can be very resistant to change, a major requirement for informed teacher practice is recognition and understanding through increased awareness of the linguistic, social, and psychological factors that are significant in classroom discourse. The following can constitute the focus of action research.

\begin{tabular}{|c|c|}
\hline Category & Reflective questions \\
\hline Linguistic & $\begin{array}{l}\text { - What aspects of my language reflect the register of the } \\
\text { discipline I teach? } \\
\text { - How accurately does my speech reflect language use in the } \\
\text { - Wecific content area? } \\
\text { - } \text { - What is the degree of linguistic complexity of my classroom } \\
\text { challenging for learners? } \\
\text { - How does my language contrast with that of my learners? } \\
\text { - What opportunities do I give for students' language growth? } \\
\text { What roles do I assign to language varieties in the } \\
\text { classroom? }\end{array}$ \\
\hline Social/Interactional & $\begin{array}{l}\text { - What speaking boundaries do I set for my learners? } \\
\text { - How do I use language as an instrument for control? } \\
\text { - How does my language help to position my students and } \\
\text { myself in classroom discourse? } \\
\text { - What is the pattern of teacher-student interaction in my } \\
\text { classroom? }\end{array}$ \\
\hline Psychological/Attitudinal & $\begin{array}{l}\text { - How does my language influence classroom climate? } \\
\text { - What does my language reveal about my attitude to } \\
\text { language varieties in the classroom? }\end{array}$ \\
\hline
\end{tabular}

Table 3. Questions for reflective practice in three categories

As I suggest in Table 3, teachers can investigate their oral language use along three dimensions: linguistic, social/interactional and psychological/attitudinal. They should be interested in the extent to which their language use accurately and appropriately reflects the registers of school disciplines. Subjects such as mathematics and science use multiple semiotic systems that students must learn to negotiate if they are to be successful (Fang \& Schleppegrell, 2010; Lager, 2006; Nagy \& Townsend, 2012; Schleppegrell, 2007). In addition, teachers serve as models for students and accurate subject-specific language use requires a degree of awareness and use of that information to construct learning environments that would allow learners to acquire the linguistic capital necessary to learn content (Zwiers, 2007). Although teachers sometimes use informal language to make content more comprehensible to students, such use where technical, subject-specific language is 
required could limit students' access to disciplinary registers and negatively affect student learning (Ernst-Slavit \& Mason, 2011).

Self-analysis aimed at increasing awareness of language use can further help teachers to recognize the complexity of texts in content areas, and be sensitive to the demands placed on students' comprehension of oral texts. Processing information while listening requires different comprehension strategies from those required when reading or viewing graphic representations. To aid students' comprehension, Moje, Collazo, Carillo, \& Marx (2001) recommend that teachers carefully select their "tools of expression" (p. 5) and recognize the multiplicity of discourses that compete in the classroom; among them, the discourse of the subject, of instruction, and of everyday life. This is an area that requires much more research to fully understand the way learners negotiate different texts in the classroom.

The tenor or relationship of participants in classroom discourse is inherently unequal. From a Bourdieuan perspective, the linguistic capital that teachers possess is not necessarily shared by students, who also have unequal access to language in school disciplines. This includes both form and discursive practices, many of which, like Initiation-Response-Feedback (IRF), are highly routinized (Zevenbergen \& Gates, 1998). The IRF structure of classroom interaction allows teachers to control the dialogue and social interactions in the classroom. This can restrict meaningful student participation in classroom discourse by decreasing opportunities for students to elaborate and explain their answers. Teachers also wield the power to direct activities and determine who speaks, when, and for how long. In this way, teachers manage classroom discourse, and teacher language affects the quantity and quality of student talk. More teacher talk results in less time for student talk, and, as Wagner (2007) observed, students have less control over the discursive systems in their classrooms. Teacher investigation of context can reveal how such systems are organized in classrooms, with a view to amending practice to ensure that students have greater opportunities to express themselves. In addition, styles of explanation and questioning need to be examined. For example, open and closed questions elicit different types of responses from students. Safford \& Kelly (2010) suggested as well that there are significant differences in styles, manners and rhetorical devices that serve as instruments to impose the official language. Reflective inquiry to improve practice can help bring greater clarity to these issues.

\section{Conclusion}

This paper addressed the relationship between teacher oral language use and students' learning environment in mathematics and science to answer two questions. The first concerned the role of teacher oral language in shaping students' learning environment. The second focused on the issue of increasing awareness of language use to promote enabling learning environments. Examination of six illustrative teaching-learning episodes and findings of other classroom language research suggest that interpersonal and social aspects of communication are as important as linguistic ones. Individual or collaborative teacher inquiry can focus on the way teacher language can act as a model for learners and increase their access to 
academic language. Teachers can also discover how language reflects their attitude and assumptions, and link to their pedagogic practice. All have a role in constructing the environment in the classroom. While the research was conducted in a Caribbean Creole context, the findings and recommendations for teacher practice have relevance for international educational settings since they can enable teacher professional growth, and help teacher educators sensitize prospective teachers to the importance of language in creating facilitative learning environments in content areas.

\section{References}

Bourdieu, P. (1977). Outline of a theory of practice. Cambridge, Eng.: Cambridge University Press.

Carrington, L. D. (1990). The linguistic situation in Trinidad and Tobago: Implications for classroom practice. Paper presented at the conference on "The Parent, the Child and Literacy" of the Committee for International Literacy Year of Trinidad and Tobago.

Cazden, C. (2001). Classroom discourse: The language of teaching and learning. Portsmouth, NH: Heineman.

Creswell, J. (2008). Educational research: Planning, conducting, and evaluating quantitative and qualitative research. $3^{\text {rd }}$ ed.) Upper Saddle River, NJ: Pearson.

Craig, D. (2006). From vernacular to Standard English: Teaching language and literacy to Caribbean students. Kingston, Jamaica: Ian Randle Publishers.

Cummins, J. (1978). The cognitive development of children in immersion programs. Canadian Modern Language Review, 34, 855-833.

Cummins, J. (1979). Linguistic interdependence and the educational development of bilingual children. Review of Educational Research, 49, 222-251.

Delpit, L. (1995). Other people's children: Cultural conflict in the classroom. New York: The New Press.

Draft Syllabus for Primary School Mathematics. (1998). Port-of-Spain, Trinidad: Government of the Republic of Trinidad and Tobago.

Ernst-Slavit, G., \& Mason, M. (2011). "Words that hold us up": Teacher talk and academic language in five upper elementary classrooms. Linguistics and Education, 22, 430-440.

Fang, Z., \& Schleppegrell, M. (2010). Disciplinary literacies across content areas: Supporting secondary reading through functional language analysis. Journal of Adolescent \& Adult Literacy, 53(7), 587-597.

Grenfell, M. (2003). Bourdieu in the classroom. Centre for Language in Education Occasional Paper, University of Southhampton, Southhampton. Available from Educational Resources Information Center (ERIC). 
Grenfell, M. (2009). Applying Bourdieu's field theory: The case of social capital and education. Education, Knowledge \& Economy, 3(1), 17-34.

Halliday, M. A. K. (1978). Language as social semiotic. London: Edward Arnold.

Halliday, M. A. K. (1993). Towards a language-based theory of learning. Linguistics and Education, 5(2), 93-116.

Heath, S. B. (1983). Ways with words: Language, life, and work in communities and classrooms. Cambridge, Eng.: Cambridge University Press.

Lager, C. (2006). Types of mathematics reading interactions that unnecessarily hinder algebra learning and assessment. Reading Psychology, 27(2-3), 165204.

Lemke, J. L. (1990). Talking science: Language, learning, and values. Norwood, NJ: Ablex.

Miles, M., \& Huberman, A. M. (1994). Qualitative data analysis: An expanded sourcebook. 2nd ed. Thousand Oaks, CA: SAGE Publications.

Moje, E., Collazo, T., Carillo, R., \& Marx, R. (2001). “Maestro, what is 'quality'?": Language, literacy, and discourse in project-based science. Journal of Research in Science Teaching, 38(4), 469-698.

Nagy, W., \& Townsend, D. (2012). Words as tools: Learning academic vocabulary as language acquisition. Reading Research Quarterly, 47(1), 91-108.

Nassaji, H., \& Wells, G. (2000). What's the use of "triadic dialogue"?: An investigation of teacher-student interaction. Applied Linguistics, 21(3), 376-406.

Safford, K., \& Kelly, A. (2010). Linguistic capital of trainee teachers: Knowledge worth having? Language and Education, 24(5), 401-414.

Schleppegrell, M. J. (2007). The linguistic challenges of mathematics teaching and learning: A research review. Reading \& Writing Quarterly, 23, 139-159.

Simmons-McDonald, H. (2004). Trends in teaching standard varieties to creole and vernacular speakers. Annual Review of Applied Linguistics, 24, 187-208.

Stake, R. E. (2010). Qualitative research: Studying how things work. New York: Guilford Press.

Syllabus for Primary School Science. (2003). Port-of-Spain, Trinidad: Government of the Republic of Trinidad and Tobago.

Tsay, J., Judd, A., Hauk, S., \& Davis, M. (2011). Case study of a college mathematics instructor: Patterns of classroom discourse. Educational Studies in Mathematics, 78, 205-229.

van Goor, R., \& Heyting, F. (2008). Negotiating the world: Some philosophical considerations on dealing with differential academic language proficiency in schools. Educational Philosophy and Theory, 40(5), 653-665. 
Vaish, V., \& Kiang Tan, T. (2008). language and social class: linguistic capital in singapore. Retrieved from http://hdl.handle.net/10497/3339.

Valdés, G. (2004). Between support and marginalization: The development of academic language in linguistic minority children. Bilingual Education and Bilingualism, 7(2\&3), 102-132.

Vacca, R. T., Vacca, J. A. L., \& Mraz, M. (2011). Content area reading: Literacy and learning across the curriculum. $10^{\text {th }}$ ed. Boston: Allyn \& Bacon.

Vollmer, H. J. (2007). Language across the curriculum: A way towards plurilingualism. In W. Martinyuk (Ed.), Towards a common European framework of reference for languages of school education (pp. 177-192). Krakow: Universitas.

Vollmer, H. J. (2009). Language across the curriculum. Proceedings from the Conference of Languages in Education, Ljubljana, Slovenia (pp. 27-39).

Wagner, D. (2007). Students' critical awareness of voice and agency in mathematics classroom discourse. Mathematics Thinking and Learning, 9(1), 31-50.

Zevenbergen, R., \& Gates, P. (1998). Classroom interactions and linguistic capital: A Bourdieuian analysis of the construction of social difference in mathematics education. Proceedings from the First International Mathematics Education \& Society Conference (MEAS1) (pp. 360-366).

Zwiers, J. (2007). Teacher practices and perspectives for developing academic language. International Journal of Applied Linguistics, 17(1), 93-116. 